\title{
Article
}

\section{Attitudes towards prisoner-to-prisoner bullying and the association with prison environments: Examining the components.}

Ireland, Jane Louise, Ireland, Carol Ann and Power, Christina L Available at http://clok.uclan.ac.uk/12921/

Ireland, Jane Louise ORCID: 0000-0002-5117-5930, Ireland, Carol Ann ORCID: 0000-0001-7310-2903 and Power, Christina L (2016) Attitudes towards prisoner-to-prisoner bullying and the association with prison environments: Examining the components. Journal of Aggression, Conflict and Peace Research, 8 (2). pp. 124-136. ISSN 1759-6599

It is advisable to refer to the publisher's version if you intend to cite from the work. http://dx.doi.org/10.1108/JACPR-05-2015-0172

For more information about UCLan's research in this area go to http://www.uclan.ac.uk/researchgroups/ and search for <name of research Group>.

For information about Research generally at UCLan please go to http://www.uclan.ac.uk/research/

All outputs in CLoK are protected by Intellectual Property Rights law, including Copyright law. Copyright, IPR and Moral Rights for the works on this site are retained by the individual authors and/or other copyright owners. Terms and conditions for use of this material are defined in the policies page.

\section{CLoK}

Central Lancashire online Knowledge www.clok.uclan.ac.uk

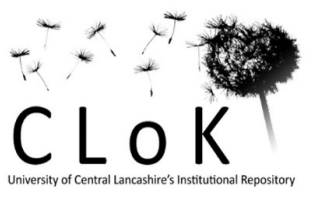




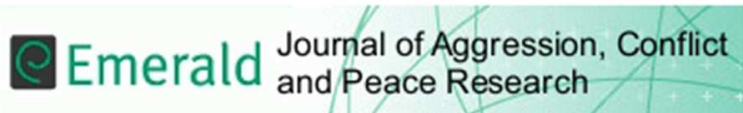

Attitudes towards prisoner-to-prisoner bullying and the association with prison environments: Examining the components.

\begin{tabular}{|r|l|}
\hline Journal: & Journal of Aggression, Conflict and Peace Research \\
\hline Manuscript ID & JACPR-05-2015-0172.R2 \\
\hline Manuscript Type: & Empirical Paper \\
\hline Keywords: & $\begin{array}{l}\text { prison bullying, prisoners, prison officers, attitudes to aggression, } \\
\text { aggressive environments, prison aggression }\end{array}$ \\
\hline \multicolumn{2}{|c}{} \\
\hline
\end{tabular}

SCHOLARONE ${ }^{\text {IM }}$

Manuscripts 


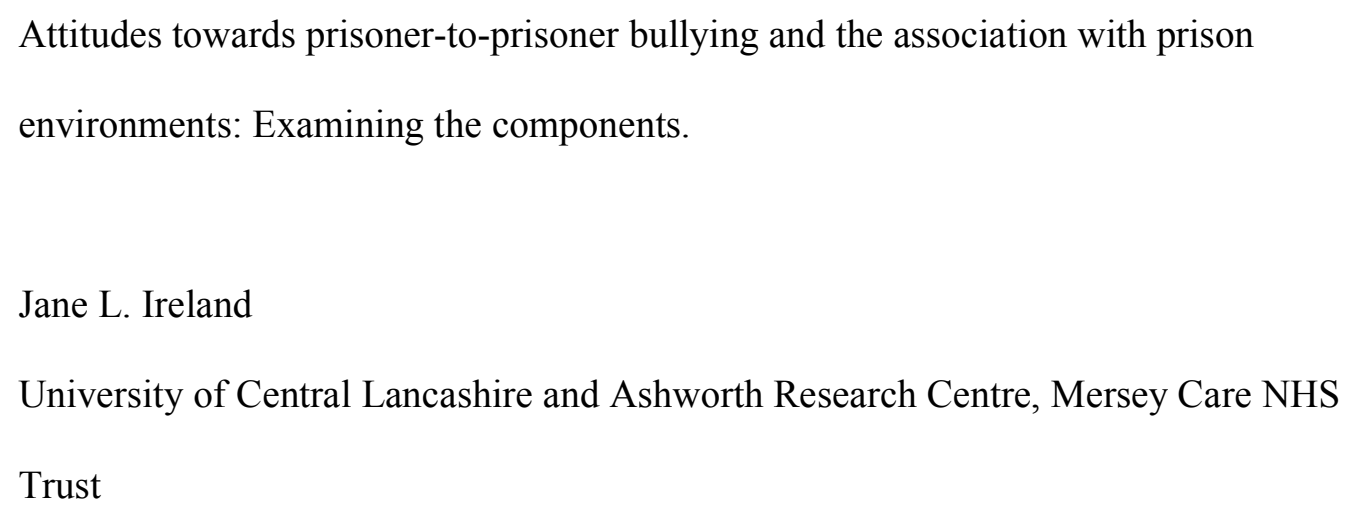




\begin{abstract}
Purpose: The research aims to examine attitudes towards prisoner-to-prisoner bullying, further considering the association between attitudes and characteristics of the prison environment thought to promote prisoner bullying.

Methodology: Questionnaires were administered to 423 adult male prisoners and 195 correctional officers from three prisons in Canada. Participants completed the Prison Bullying Scale (PBS) and the Prison Environmental Scale (PES).

Findings: Convergence in attitudes between prisoners and officers were noted although staff were more likely to consider bullies to be skilled, whereas prisoners were more likely than officers to feel that victims of bullying should be supported. Associations between attitudes supportive of bullying and environmental characteristics likely to promote prison bullying were found primarily among prisoners; the strongest predictors of such attitudes were poor relationships (e.g. prisoner to officer; prisoner to prisoner).

Research implications: The study highlights the importance of the social aspect of the prison environment. It further provides an outline of two measures that could have utility in evaluating interventions designed to reduce prisoner-to-prisoner bullying. Originality/value: The study is the first to examine attitudes in a combined sample of prisoners and officers and focuses on the role of the wider prison environment. It also utilises a sample from three prisons as opposed to focusing on a single establishment.
\end{abstract}


Researchers have begun to suggest that prison bullying is well researched (e.g. Nelson, Woodhams \& Hatcher, 2010). This may represent a generous interpretation of a literature base that has been in existence for almost two decades (Ireland \& Archer, 1996; Connell \& Farrington, 1997) but has actually produced only a limited range of papers across such a considerable period of time. It would further appear that papers on this topic in more recent years have failed to properly convey an understanding of the definitional challenges in this area, drawn conclusions by considering a selective review of available research, argued for the need to consider particular variables without any attention to theory, concluded that certain areas of research have not been addressed when in fact they have, or focused on very small datasets, claiming their work is sufficiently novel to allow for this (e.g. Kiriakidis, 2010; Nelson et al, 2010; Wood, Moir \& James, 2009).

Consequently, it would seem that in recent years studies and reviews are emerging that offer little to advance this important research topic. The focus on descriptive research, devoid of theory, is one of the most concerning elements of this research base. Earlier research could be forgiven the absence of a theoretical base since there was virtually no research to guide theory. This argument no longer holds and consideration of random variables alongside bullying that is not guided by theory does nothing to progress this important area of study.

Regardless of the relatively slow rate of progress in research, bullying in prisons remains an important topic worthy of increased attention. For example, if asked about perceptions of bullying as a problem some studies produce estimates of bullying as high as 81 per cent (Dyson, 2005). If asking directly 'Have you bullied/been bullied' estimates will drop to around ten to twenty per cent (Ireland, 2012). If behavioural checklists are used (where the term bullying is avoided but abusive behaviours are captured discretely), then estimates are as high as 65 per cent 
reporting perpetration in the past month and 81 per cent reporting victimisation in the past month (Chan \& Ireland, 2009), with other studies reporting rates of 39 per cent for perpetration and 60 per cent for victimisation in the past week (Wood et al, 2009). Considering the size of the prison population in the UK (where virtually all research has been completed), this would produce minimum estimates of around 9,000 prisoners being bullied in any given month if asked directly about their experiences, and a maximum of 69,000 prisoners reporting at least one behaviour that could be considered bullying in any single month (based on UK prison population figures for the $15^{\text {th }}$ May 2015).

These are startling estimates that question why research has been so limited in quantity and scope. Some studies have certainly attempted to progress the area by moving beyond descriptive research to offering some theoretical interpretations of the behaviour (e.g. Ireland \& Archer, 2002; South \& Wood, 2006; Wood et al, 2009; Archer \& Southall, 2009). Most recently this has led to the development of the Multifactor Model of Bullying in Secure Settings (MMBSS; Ireland, 2012), a revised version of the earlier Interactional Model of Prison bullying (IMP: Ireland, 2002). The MMBSS attempted to integrate the literature on prison bullying with the wider aggression literature and factors known to promote aggression (e.g. General Aggression Model, GAM: Anderson \& Bushman, 2002 and the Integrated Information Processing model, Huesmann, 1998). The product was a model that accounted for individual characteristics and the wider social and physical environment known to promote prison bullying.

The MMBSS describes how the route to perpetrating bullying can be via two core pathways, both informed by the social environment. One pathway ('environment and prior characteristic') considers bullying as a function of the individual characteristics of the prisoner and the unhelpful aspects of both the social and physical environment. This includes, for example, restrictions on material goods, low 
spatial density, relational security [physical environment], hierarchal structures, low attachments and high social density [social environment]. The pathway argues for an interaction between unhelpful individual characteristics (e.g. impulsivity, considerable experience of secure care), and the environment prisoners find themselves as the factors that raise the propensity for bullying. The other MMBSS pathway is termed the 'desensitisation pathway'. Here, the contextual factors associated with aggression (e.g. perceived risk of aggression in the environment; frequency of aggression in the environment; limited options to deal with aggression), coupled with a higher perceived threat of aggression, creates desensitisation to aggression. This pathway is thought to enhance pre-existing stable but potentially changeable individual characteristics (in the form of beliefs and attitudes) likely to encourage aggression and lead to victim blaming and attitudes that minimise the consequences of bullying for victims. There is an expected crossover between both pathways in the MMBSS but what is common is the importance of the environment and in particular attitudes.

Attitudes are thus integral to models describing bullying within prison settings, forming a key component of the social environment. Some research has explored the role of attitudes in prison bullying (e.g. Connell \& Farrington, 1996; Ireland, 1999; Dyson, 2005; Spain, 2005; Ireland, Power, Bramhall \& Flowers, 2009). Such attitudes have been found to be multidimensional, with Ireland et al (2009) noting the following core attitudinal components; justification of bullying; negative views towards victims; negative views towards bullies; respecting bullies and the consequences of their actions; bullies as strong and skilful; victims seeking attention; and victims deserving of bullying. A positive association between bullying perpetration and aggression supporting beliefs, including victim-blaming beliefs (e.g. Ireland, 1999), has been reported.

Nevertheless, research into the attitudinal component of the social environment of prisons has been remarkably limited and centred on attitudes held by prisoners (e.g. 
Ireland et al, 2009). It has failed to capture the wider social environment, such as prison officer attitudes, or to consider how attitudes may be associated with the environment more broadly. This is important since models such as the MMBSS place considerable emphasis on attitudes and yet we know only a limited amount concerning their content, structure and presence across the prison environment.

Interventions on prison bullying would also benefit from more exploration of this area. There is an absence of evaluation of bullying interventions in the prison literature (Kiriakidis, 2010) and yet the development of measures could assist evaluation.

Examining further environmental measures, namely those that incorporate an attitudinal component that can be applied across prisoners and staff, would seem to represent a particularly valuable avenue of research to pursue.

The current research aims to address this neglected area of study by exploring attitudes towards prisoner-to-prisoner bullying in a sample of male prisoners and a sample of prison officers from three prisons in Canada ${ }^{1}$. It aims to consider the factors that comprise attitudes and how attitudes are associated more broadly with the social and physical environmental characteristics thought to promote bullying among prisoners.

The following core predictions are made:

1.) Attitudes supportive of prison bullying will be positively associated with perceptions of the social and physical components of the environment thought to promote bullying;

2.) There will be no overall differences between the attitudes expressed towards bullying by prisoners and officers, by virtue of them sharing the same environment.

\footnotetext{
${ }^{1}$ Data exploring bullying and gang related behaviours were also collected but published as part of a separate paper (Ireland \& Power, 2012). The data presented in the current paper, aside from sample description, is distinct in focus.
} 
Method

Participants

Participants were sampled from three separate establishments in one region in Canada. It included two medium secure establishments (Prisons A and B) and one high secure (Prison C). All establishments followed the same standard structural format (i.e. cell based accommodation) and all housed male prisoners.

Six hundred and eighteen questionnaires were returned; 423 questionnaires from adult male prisoners (222 from Prison A; 66 from Prison B and 135 from Prison C). One hundred and ninety five questionnaires were returned from prison officers (116 Prison A; 38 Prison B; 41 Prison C). For Prison A this represented 54\% of the total prison officer population and $40 \%$ of the total prisoner population at the time of sampling; For Prison B it represented $20 \%$ of the total prison officer population and $13 \%$ of the total prisoner population at the time of sampling; For Prison $\mathrm{C}$ this represented $17 \%$ of the total prison officer population and $28 \%$ of the total prisoner population at the time of sampling.

The average age of prisoners was 34.6 years (sd 10.2), average total time served in prison was 110 months (sd 93.6), and length of current sentence 63.8 months (sd 93.6). Across offences, 50.6\% were serving for a violent offence, $16.1 \%$ for a drug-related offence, $14.9 \%$ for an acquisitive offence, $2.8 \%$ for a sex offence and $5.7 \%$ for an 'other' offence $(9.9 \%$ did not indicate their offence type). The average age of officers was $37.3(\mathrm{sd}=9.0)$, average length of time serving as a prison officer was 107.3 months $(\mathrm{sd}=112)$, and average length of time serving within the prison of interest was 96.9 months $(\mathrm{sd}=106)$. Seventy-six percent of the officer sample were men. Tables 1 and 2 present prisoner characteristics across establishments.

$<$ Insert Table 1 here $>$

$<$ Insert Table 2 here $>$ 
There were no significant differences with regard to officer variables across prison sites (all F's $\geq 2.16 \mathrm{~ns}$ ). Regarding prisoners, there was a significant difference with regards to age; Prison A had significantly younger prisoners than Prisoner B (p $<.02)$ and Prisoner $\mathrm{C}(\mathrm{p}<.04)$. Significant differences were also found across prison sites with regards to offence type $\left(\mathrm{X}^{2}=27.1, \mathrm{p}<.003\right)$; Prison A presented with the higher proportion of drug-related offences than Prison $\mathrm{C}$, and had the lowest proportion of prisoners currently convicted for violence.

Measures

Prisoners and officers completed the following measures:

Prison Bullying Scale (PBS: Ireland et al, 2009). This 39-item measure explores attitudes towards prisoner-to-prisoner bullying. It is scored on a scale ranging from 1 (strongly disagree) to 7 (strongly agree). Example items include "you should not pick on someone weaker than you" and "victims usually cause the bullying to happen". A higher score indicates attitudes supportive of bullying.

Prison Environmental Scale (PES: Allison \& Ireland, 2010). This 40-item measure contains statements reflecting physical and social environmental factors thought to promote bullying in prisons. It draws on the components of the MMBSS to identify the relevant social and environmental factors. Thus, physical factors covered material goods, changes in the prisoner population, the frequency and visibility of staff supervision and lack of stimulation. Social factors covered the organisational structure, the prisoner subculture, attitudes towards bullying, and power and dominance structures. Each item is scored on a scale ranging from 1 (strongly disagree) through to 5 (strongly agree). Example items include "there is not much physical space" and "there is an emphasis on prison rules and regulations here". The scale focuses on perceptions of their current prison, with a higher score indicating more factors associated with a raised environmental propensity for bullying. 
Procedure

With prisoner participants, a member of staff administered all questionnaires during a lock-down period. This was completed at one time point in the same month to ensure all prisoners were approached that were present at that time. All prisoners available at the time of sampling were approached and invited to participate. Prisoners completed the questionnaires in their cell on their own and these were then returned. Prison officers were provided with a copy of the questionnaires at the start of their shift and asked to complete it by the end, again at one time point in the same month. The questionnaires were anonymous. All analyses were conducted using SPSS. Results

Results are presented with regards to attitudes first (PBS), followed by the environment scale (PES), before considering how attitudes and the environment may relate. Each set of analyses also explores the structure of the PBS and the PES.

\section{Attitudes towards prison bullying}

The PBS was found to be internally reliable (prisoners: $\alpha=.83,39$ items, $\mathrm{n}=$ 343, 80 missing; officers: $\alpha=.79,39$ items, $\mathrm{n}=184,11$ missing; overall $\alpha=.82,39$ items, $\mathrm{n}=527,91$ missing). Scores on the PBS ranged from 39 to 226 . Mean scores are presented in Table 3.

$<$ Insert Table 3 here $>$

There were no significant differences between prisoners and officers regarding total PBS attitudes $(\mathrm{F}=.86 \mathrm{~ns})$. There were also no differences across prison site $\left(\mathrm{F}^{\prime} \mathrm{s} \geq\right.$ $=.86 \mathrm{~ns})$. 


\section{Structure of attitudes towards bullying}

The structure of the PBS was examined using factor analysis. In order to more strictly identify the number of factors evident, Parallel Analysis (PA) was employed. This analysis indicated four factors across the overall sample (prisoners and officers), with no indication of a need to complete separate factor analyses for prisoners and officers. This was also confirmed via a scree plot. The factor analysis therefore proceeded restricting the analysis to four factors. Principal Components Analysis with Varimax Rotation was employed. The results are presented in Table 4. Only one item failed to load above .40 , namely 'once someone is a bully, they are always going to be a bully'. This was therefore removed from the analysis. With regard to each factor, factor one comprised 14 items with a theme of 'admiring bullies and negatively appraising victims'; factor two comprised 10 items with a theme of 'supporting and defending victims'; factor three comprised nine items with a theme of 'justifying bullying and considering victims as deserving of bullying'; factor four comprised five items with a theme of 'bullies as skilled'.

$<$ Insert Table 4>

Factor scores were then computed to allow the attitude totals to be used in further analyses. To compute a factor score only items loading above .50 were included, in accordance with the recommendation from Tabachnick \& Fidell (2013). Adopting higher factor loadings when creating factor scores ensures that what is included in the factor score are only those most representative of that factor and those items only loading onto a single factor ${ }^{2}$. This resulted in 13 items comprising factor one, nine comprising factor two, seven for factor three, and two for factor four. The totals are presented in Table 5. Higher scores indicate more support for the factor.

\footnotetext{
${ }^{2}$ The factor analysis tables still present all item loadings so readers can determine what was not included in the factor score.
} 


\section{$<$ Insert Table 5>}

Differences between prisoners and officers were explored using ANOVA across each PBS factor. Significant differences were limited to the factors 'supporting victims' $(\mathrm{F}=6.51, \mathrm{p}<.001)$, and 'bullies as skilled' $(\mathrm{F}=10.6, \mathrm{p}<.001)$. Prisoners reported more positive attitudes than officers with regard to supporting victims, with officers more likely to consider bullies to be skilled. There were no differences across prison site (F's $\geq=2.64 \mathrm{~ns})$.

The role of the prison environment

The PES focused on the social and physical aspects of prison environments thought to increase the propensity for aggressive behaviour between prisoners. It proved to have moderately high reliability across samples (overall $\alpha=.74, \mathrm{n}=514$; prisoner $\alpha=.78, \mathrm{n}=330$; officer $\alpha=.67, \mathrm{n}=184$ ). Table 6 illustrates the means for the PES overall and for prisoners and officers.

$<$ Insert Table 6 here $>$

There was a significant difference across groups (prisoners vs. officers) $(\mathrm{F}=$ 7.37, $\mathrm{p}<.007)$. Officers reported higher scores on the PES than prisoners, indicating that they were more likely to identify aspects of the prison environment that encouraged bullying. There was also a significant difference across prison sites, with Prison A presenting with higher scores than the remaining prisons $(\mathrm{F}=4.31, \mathrm{p}<.01)$

\section{$\underline{\text { Structure of the Prison Environment Scale (PES) }}$}

In order to determine if specific elements of the environment distinguished between sites, the structure of the PES was examined using factor analysis. Parallel Analysis (PA) was employed to identify the number of factors. This analysis indicated six factors, with similarity across samples. Thus a single factor analysis was 
completed, restricting the analysis to six factors using Principle Components Analysis with Varimax Rotation. The results are presented in Table 7. Six items failed to load above .40 , indicating a 34 -item scale. The items failing to load were as follows; there is enough personal space; prisoners know the other prisoners around them long enough to trust them; there is an emphasis on prison rules and regulations here; rules telling prisoners what they can have are clear; the opportunity to have social contact is good; and prisoners won't back down if challenged.

The analysis therefore proceeded with a 34 -item scale. The variance contribution of each factor is illustrated in Table 8. With regard to each factor: factor one comprised 11 items with a theme of "existence of a hierarchy and importance of material goods'; factor two comprised seven items with a theme of 'lack of access to activities and space'; factor three comprised three items with a theme of 'predictable staff supervision'; factor four comprised four items with a theme of 'core beliefs: accepting bullying'; factor five comprised four items with a theme of 'lack of control', specifically the absence of reliance on security and control and reduced penalties for poor behaviour; factor six comprised four items with a theme of 'prisoner and staff relationships', with the items most representative of this indicating poor relationships.

$<$ Insert Table 7>

Factor scores were computed to allow the factor totals to be used in further analyses. To compute a factor score only items loading above .50 were included (Tabachnick \& Fidell, 2013). These resulted in nine items comprising factor one; five items comprising factor two; three items comprising factor three; three items comprising factor four, and two items for factors five and six. The totals are presented in Table 8. Higher scores indicate more support for the factor. 


\section{$<$ Insert Table 8>}

Differences between prisoners and officers were explored using ANOVA. There was a significant difference with regard to the factor 'existence of a hierarchy and importance of material goods' $(\mathrm{F}=72.4, \mathrm{p}<.0001)$, with officers reporting higher perceptions of hierarchy and trading than prisoners. There was also a significant difference with regard to the factor 'lack of access to activities and space' $(\mathrm{F}=177.9, \mathrm{p}<.001)$, with prisoners reporting higher perceptions of an absence of activities than officers.

Prison A presented with higher scores than prison $\mathrm{C}$ in relation to 'existence of a hierarchy' $(\mathrm{F}=3.72, \mathrm{p}<.03)$. There was also a difference across prison sites in relation to 'predictable staff supervision $(\mathrm{F}=6.93, \mathrm{p}<.001)$, with prison A presenting with higher scores than prison $\mathrm{B}(\mathrm{p}<.001)$, and prison $\mathrm{C}$ with higher scores than prison $B(p<.001)$. 'Core beliefs: accepting bullying' $(F=6.34, p<.002)$ were also higher in prison $\mathrm{A}$ than prison $\mathrm{B}(\mathrm{p}<.02)$ and prison $\mathrm{C}(\mathrm{p}<.005)$.

Association between the prison environment and attitudes towards bullying

Correlations were produced across total and factor scores on the PBS and for the PES. Significant correlations were limited and of small magnitude. There was a small correlation between high total PBS and high total PES scores $(r=.16, p<.001$, $\mathrm{n}=454$ ), with the total PES score also positively correlating with the PBS subscales 'admiring bullies and negatively appraising victims' $(\mathrm{r}=.14, \mathrm{p}<.002, \mathrm{n}=471)$ and 'justifying bullying and considering victims deserving of bullying' $(r=.24, p<.001, n$ $=482$ ).

Unsurprisingly the majority of correlations were between the PES subscale 'core beliefs accepting bullying' and the PBS, with positive correlations between this subscale and the PBS total $(\mathrm{r}=.27, \mathrm{p}<.001, \mathrm{n}=.49)$, and with the PBS subscales of 'justifying bullying and considering victims as deserving of bullying' $(r=.25, \mathrm{p}$ $<.001, \mathrm{n}=528)$, and 'admiring bullies and negatively appraising victims' $(\mathrm{r}=.28, \mathrm{p}$ 
$<.001, \mathrm{n}=513$ ). There was a negative correlation between the PES subscale core beliefs and the PBS subscale 'supporting and defending victims' $(r=-.16, p<.001, \mathrm{n}$ $=527)$.

There were also significant positive correlations between the PES subscale 'predictable staff supervision' and the PBS subscale 'justifying bullying and considering victims as deserving of bullying' $(\mathrm{r}=.11, \mathrm{p}<.01, \mathrm{n}=525)$, and between the PES subscale 'prisoner and staff relationships' and the PBS subscale 'supporting and defending victims' $(\mathrm{r}=.13, \mathrm{p}<.003, \mathrm{n}=524)$.

There was further consideration of the extent to which aspects of the prison environment, as measured by the PES, were related to attitudes towards bullying. It was assumed that the prison environment was influencing attitudes rather than the reverse. This was considered overall and separately across prisoners and officers using regression analyses. In light of the correlations between the PES subscale 'core beliefs' and the PBS this particular subscale was excluded from the analysis. The regression continued therefore with the PBS total score as the variable regressed onto and with the remaining five PES subscales as the potential predictors (i.e. existence of a hierarchy and importance of material goods; lack of access to activities and space; predictable staff supervision; lack of control; and prisoner and staff relationships).

The overall regression comprising the total sample (prisoners and officers) did not produce a significant model $(\mathrm{F}=1.78 \mathrm{~ns})$. Consequently, two further regressions were completed, across officers and prisoners respectively. The model in relation to officers was not significant $(\mathrm{F}=1.49 \mathrm{~ns})$. For prisoners, however, a significant model was produced $(\mathrm{F}=4.12, \mathrm{p}<.001)$. Overall attitudes towards bullying were predicted by the following PES subscales; higher 'existence of a hierarchy and importance of material goods' $(\mathrm{B}=1.05, \mathrm{SE} .36, \mathrm{t}=2.9, \mathrm{p}<.003)$, lower perception of a 'lack of control' $(\mathrm{B}=-3.09, \mathrm{SE} 1.43, \mathrm{t}=2.16, \mathrm{p}<.03)$ and poorer 'prisoner and staff relationships' ( $\mathrm{B}=3.46, \mathrm{SE} 1.1, \mathrm{t}=3.19, \mathrm{p}<.002)$. 


\section{Discussion}

The current study provides an indication of the nature of attitudes and components of the social and physical environments that are associated with unhelpful attitudes supporting prison bullying. There was overall convergence between prisoners and officers on the attitudinal and environmental measures but interesting differences emerged in the association between these measures. For example, as predicted, there was a positive association between overall attitudes supportive of bullying and the aspects of the prison environment thought to increase the risk for prison bullying. Although the magnitude of this relationship was small it nevertheless supported the theoretical argument put forward by interactional models of prison bullying (Ireland, 2005; Ireland, 2012), namely that if the environment has characteristics likely to raise the risk for bullying then attitudes supporting bullying would similarly co-exist. However, on further exploration the environmental predictors of attitudinal components were restricted to prisoners and to specific components.

This restriction to prisoners is perhaps unsurprising since prisoners would be expected to perceive the broader prison environment in somewhat distinct terms to prison officers. The limited components of the environment shown to predict attitudes was, nevertheless, surprising and suggests that only discrete elements of the environment may be important. Among prisoners, for example, attitudes were predicted by a perception that the environment promoted hierarchy and placed importance on material goods, with an absence of enforced penalties for negative behaviour and poor relationships with others. Although aspects of both the social and physical environment were presenting as important, it did appear that the social aspects (e.g. relationships, hierarchy) were particularly important components. This fits with expectations of the interactional models (e.g. MMBSS, Ireland, 2012; IMP, 
Ireland, 2002) but places emphasis on the role of the social environment. It suggests that focusing on community relationships (i.e. social hierarchies, relationships) may hold some value for prison-wide bullying interventions. The current study points to the importance of developing a healthy social environment in that an unhealthy social environment where individuals lack good relationships, feel unsafe and where dominance hierarchies are higher appeared particularly predictive of attitudes supportive of prison bullying.

The role of the social environment here is thus consistent with the concept of a 'healthy community' where behaviour (i.e. bullying) is not pathologised as an individual problem but treated as a community issue. This is not a new concept and has been highlighted as valuable in prison research (Ireland, 2008; Ireland, 2012). It could, nevertheless, be argued that considerably more effort should be spent on developing healthy communities than on efforts centred on individual approaches to dealing with bullying (e.g. perpetrator programmes; victim support programmes). The current study lends some tentative support for this by highlighting how the broader elements of the environment are related to unhelpful attitudes towards bullying, particularly among the prisoner community. The current findings also touch upon a factor that is not well articulated within the MMBSS, namely that of atmosphere and the importance of perceiving the environment to be a safe one where negative behaviour is monitored and addressed through appropriate sanctions. The presence of such factors appears to be promoting unhelpful attitudes towards bullying and yet does not present as an explicit factor in the interactional models. Rather, it appears more implicit and part of wider factors. The current study suggests value in articulating the concept of a safe atmosphere as an explicit component of the environment to consider.

A further important element of the current study that is important not to neglect is its examination of both prisoners and officers. The combination of these 
two populations has not been accounted for in previous research. The absence of officers as an important component of the research into prisoner-to-prisoner bullying is an interesting omission considering how officers are integral to the social environment of a prison and enforce many aspects of the physical environment. Models of prison bullying have long argued for attention to be increased on the environmental factors associated with prison bullying (Ireland, 2005; Ireland, 2012) in an attempt to avoid an over-focus on individual pathology models of prisoner-toprisoner bullying. Thus, incorporating officer samples appears an essential component and adds to the developing literature on attitudes towards prisoner bullying (e.g. Connell \& Farrington, 1996; Dyson, 2005; Spain, 2005; Ireland, 1999; Ireland et al, 2009). It also fits with an emerging factor in the PES scale, namely 'prisoner and prisoner-to-staff relationships', with this a core predictor for attitudes supportive of bullying. Thus, the importance of considering relationships with staff is clearly indicated.

As noted earlier, what the current study has indicated is the convergence between prisoners and officers on overall attitudes supportive of prison bullying, thus supporting the prediction. The similarity in attitudes between prisoners and staff highlights the influence of the social environment as an important and shared feature of prison environments. This supports models such as the MMBSS that describe the social environment as a shared feature across prisoners and staff and not one that is necessarily experienced differently in accordance to whether you are a resident within the environment or an employee.

There were though some specific and isolated differences between prisoners and staff emerging when the underlying factors of attitudes were considered. Specifically, prisoners were found to express more supportive attitudes towards the victims of bullying than officers, with officers holding the belief that bullies were skilled. It is certainly possible that prisoners were more supportive of victims because 
of a higher risk of being victimised themselves and consequently their resulting ability to empathise with victims, whereas officers are able to adopt a more detached perspective. The concept of a 'skilled bully' is also interesting since this can represent a myth when it is considered that most bullies are also victims (Chan \& Ireland, 2009) who display a range of negative externalising behaviours indicative of poor coping. However, this is all speculative interpretation based on the evidence indicated in the current study.

Nevertheless, the broad convergence on overall attitudes within the social environment (i.e. the similarity between prisoners and officers) remains valuable to consider since it suggests it is possible to produce a standardised means of measuring attitudes towards bullying that can be used uniformly across the social population of a prison, namely with both staff and prisoners. Such measures would have considerable utility in evaluating intervention programmes designed to reduce prison bullying, with this a noted area of need (Kiriakidis, 2010). Of course, future research will be interested in the individual factors that may influence attitudes supporting bullying, such as prior experiences with institutional care, to determine if such factors need to be accounted for. This would prove a valuable consideration for future research.

Of further interest were the findings in relation to the structure of the Prison Environment Scale (PES). As for attitudes, it suggested that such a broad concept is not represented by a unitary factor but is multidimensional (Allison \& Ireland, 2010). This is in keeping with the MMBSS model of prison bullying that supports the separation of components (as opposed to using global descriptions) in order to better specify the pathways to bullying. The PES was found to comprise six factors; existence of a hierarchy and importance of material goods; lack of access to activities and space; predictable staff supervision; core beliefs accepting bullying; lack of control; and [poor] prisoner and prisoner-to-staff relationships. Differences between prisoners and officers were limited to only two components; officers were more likely 
than prisoners to report a perception of hierarchy and trading, with prisoners more likely than officers to report a lack of activities.

The study is not, however, without its limitations. Although all prisoners and officers at the time of the study were invited to take part it is not possible to indicate how representative they were of the wider prisoner/staff population at the time of sampling as this information was not available to the research team. In addition, there was some missing data to acknowledge and a low response rate, but this still retained a large enough sample to utilise. It was also focusing on the components of attitudes and environments thought to contribute to prison bullying that were consistent with the MMBSS; it was not seeking to address the pathways aspect of the MMBSS or determine a casual association since this would require a longitudinal component. This could perhaps represent a direction for future research. The current study was also limited by a focus on self-report measures to examine attitudes and environmental components that are open to reporting biases. Obtaining confirmation of the perceptions of the environment that were being reported (e.g. via record based information or observational data) would have improved the study. It would also have benefited from a wider application of measures and variables, and incorporation of both men and women across the samples (i.e. for prisoners as well as officers).

However, the current study represents a preliminary attempt to consider aspects of the social and physical environment that have received only limited attention previously, extending the sample to cover both officers and prisoners. It was also not restricted to a single prison setting, which has been a limitation of previous research. Instead, by examining three prisons covering medium to high security levels it was hoped to provide more generalisable findings. Future research could certainly look to expand on the measures collected, and perhaps to focus on the desensitisation pathway of the MMBSS model in more detail by considering the role 
of emotion and how this may associated with attitudes and the other environmental factors linked to prison bullying.

Overall the study provides some initial consideration of the components of attitudes relevant to bullying and their association with the environment, indicating convergence between prisoners and officers across most components. Despite broad similarity it does indicate how perceptions of the environment by prisoners may be predicting attitudes supportive of prison bullying. It suggests that interventions may be most effective in tackling the environmental aspects of prison settings that may be raising the propensity for unhelpful attitudes towards bullying.

\section{Practical implications}

- Interventions into prisoner-to-prisoner bullying should attend to the wider environment and not focus solely on individual pathology approaches.

- A 'whole prison' approach to intervention should be adopted, with recognition that officers and prisoners are part of the community.

- A focus on the perceived relationships between all those in this community requires consideration, with a community centred approach recommended for intervention.

- A concentrated effort is needed on evaluating and publishing interventions into prisoner-to-prisoner bullying. 
References

Allison, M. D, Ireland, J. L. (2010). Staff and prisoner perceptions of physical and social environmental factors thought to be supportive of bullying: The role of bullying and fear of bullying. International Journal of Law and Psychiatry, 33: 43-51.

Anderson, C.A, Bushman, B.J. (2002). Human aggression. Annual Review of Psychology, 53: $27-51$.

Archer, J., Southall, N. (2009). Does cost-benefit analysis or self-control predict involvement in bullying behaviour by male prisoners? Aggressive Behavior, 35: $31-40$

Chan J, Ireland J. L. (2009). Fear of bullying among adult, young and juvenile prisoners: Its association with perpetration, victimisation and behavioural predictors. International Journal of Prisoner Health, 5: 223 - 232.

Connell, A., Farrington, D.P. (1996) Bullying among incarcerated young offenders: developing an interview schedule and some preliminary results. Journal of Adolescence 19: 75-93

Connell, A., Farrington, D. P. (1997) The reliability and validity of resident, staff and peer reports of bullying in young offender institutions. Psychology, Crime and Law, 3:287-300.

Dyson, G. (2005). ‘Approaches to examining bullying among Young Offenders within an institutional environment: Triangulation of questionnaires and focus groups.' In J. L Ireland (Ed.), Bullying among Prisoners: Innovations in Theory and Research, Hove: Willan Publishing, UK.

Huesmann, L. R (1998) The role of social information processing and cognitive schema in the acquisition and maintenance of habitual aggressive behaviour, In R. G. Geen and E. Donnerstein (Ed.), Human Aggression: Theories, Research, and Implications for Social Policy (73- 109). London: Academic Press Ltd. 
Ireland, J L., Archer, J (1996). Descriptive analysis of bullying in male and female adult prisoners. Journal of Community \& Applied Social Psychology. 6: 35-47.

Ireland, J. L. (1999). Provictim attitudes and empathy in relation to bullying behaviour among prisoners. Legal and Criminological Psychology, 4: 51 - 66.

Ireland, J. L. (2002). Bullying Among Prisoners: Evidence, Research and Intervention Strategies, Brunner-Routledge, UK.

Ireland, J. L. (Ed.) (2005). Bullying Among Prisoners: Innovations in Theory and Research. Willan Publishing.

Ireland, J. L. (2008). ‘Bullying Among Prisoners', in G. Towl. D. Farrington, D. Crighton, G Hughes (Eds.). Dictionary of Forensic Psychology, BPS Blackwell.

Ireland, J. L. (2012). Understanding bullying among younger prisoners: recent research and introducing the Multifactor Model of Bullying in Secure Settings. International Journal of Adolescent Medicine and Health, 24: 63-68.

Ireland, J. L., Archer, J., (2002). The perceived consequences of responding to bullying with aggression: A study of male and female adult prisoners. Aggressive Behavior, 28: $257-272$.

Ireland, J. L., Power, C. P., Bramhall, S., Flowers, C. (2009). Developing an attitude towards bullying scale for prisoners: Structural analyses across adult men, young adults and women prisoners. Criminal Behaviour and Mental Health, 19: 28 - 42.

Ireland, J. L. \& Power, C. L., (2012). Propensity to support prison gangs: Its relationship to gang membership, victimisation, aggression and other disruptive behaviors. Psychology, Crime and Law, 19: $801-816$.

Kiriakidis, S. P. (2010). Bullying in penal settings: Empirical findings and suggestions for future research. Journal of Behavior Analysis in Offender and Victim Treatment, 2: $124-132$.

Nelson, A., Woodhams, J., Hatcher, R. (2010). Female prisoners' understanding of 
'bullying' and their methods of coping: a multinational perspective. Psychology, Crime \& Law, 16: $649-670$.

South, C. R., Wood, J. (2006). Bullying in prisons: The importance of perceived social status, prisonization and moral disengagement. Aggressive Behavior, 32, $490-501$.

Spain, A. (2005) 'Bullying among Young Offenders: Findings from a qualitative study' in J. L. Ireland (Ed). Bullying among Prisoners: Innovations in Theory and Research, Hove: Willan Publishing: UK.

Tabachnick, B. G, Fidell, L. S. (2013). Using Multivariate Statistics, 6th Ed. Boston: Pearson.

Wood, J., Moir, A., James, M. (2009). Prisoners' gang-related activity: The importance of bullying and moral disengagement. Psychology, Crime and Law, 15: 569 - 581. 
Table 1. Description of prisoner sample with regards to age, total time served in months, and length of sentence.

\begin{tabular}{|c|c|c|c|c|c|c|}
\hline \multirow[t]{3}{*}{ Prison } & \multicolumn{6}{|c|}{ Prisoner descriptive information } \\
\hline & \multicolumn{2}{|c|}{$\begin{array}{c}\text { Age } \\
\text { (years) }\end{array}$} & \multicolumn{2}{|c|}{$\begin{array}{l}\text { Total time } \\
\text { served } \\
\text { (mths) }\end{array}$} & \multicolumn{2}{|c|}{$\begin{array}{c}\text { Length of } \\
\text { sentence } \\
\text { (mths) }\end{array}$} \\
\hline & $\begin{array}{c}\text { Mean } \\
\text { (n) }\end{array}$ & $\begin{array}{c}\text { Range } \\
\text { (s.d.) }\end{array}$ & $\begin{array}{c}\text { Mean } \\
\text { (n) }\end{array}$ & $\begin{array}{c}\text { Range } \\
\text { (s.d) }\end{array}$ & $\begin{array}{c}\text { Mean } \\
\text { (n) }\end{array}$ & $\begin{array}{r}\text { Range } \\
\text { (s.d) }\end{array}$ \\
\hline $\begin{array}{l}\text { Prison A } \\
(\mathrm{n}=222)\end{array}$ & $\begin{array}{l}33.1 \\
(213)\end{array}$ & $\begin{array}{l}18-70 \\
(10.1)\end{array}$ & $\begin{array}{c}104 \\
(203)\end{array}$ & $\begin{array}{l}1-408 \\
(84.6)\end{array}$ & $\begin{array}{l}66.6 \\
(201)\end{array}$ & $\begin{array}{l}1-442 \\
(53.3)\end{array}$ \\
\hline Prison B & 37.2 & $21-61$ & 114.9 & $2-396$ & 66.7 & $24-300$ \\
\hline$(n=66)$ & (64) & $(10.4)$ & $(63)$ & $(99.0)$ & $(52$ & $(99.0)$ \\
\hline Prison C & 35.9 & $19-66$ & 119.6 & $1-480$ & 57.0 & $24-222$ \\
\hline$(\mathrm{n}=135)$ & $(127)$ & $(10.0)$ & $(126)$ & $(104.1)$ & $(108)$ & $(45.0)$ \\
\hline Overall & 34.6 & $18-70$ & 110 & $1-480$ & 63.8 & $1-480$ \\
\hline$(\mathrm{n}=423)$ & $(404)$ & $(10.2)$ & (392) & (93.6) & $(361)$ & (93.6) \\
\hline
\end{tabular}


Table 2. Description of prisoner sample with regards to offence type. 
Table 3. Total PBS scores overall and for prisoners and officers.

\begin{tabular}{lc}
\hline PBS Total & Mean (SD) \\
\hline Overall $(\mathrm{n}=527,91$ missing) & $107.5(29.8)$ \\
Prisoners $(\mathrm{n}=434,80$ missing) & $108.2(37.5)$ \\
Officers $(\mathrm{n}=184,11$ missing) & $107.5(29.8)$ \\
\hline
\end{tabular}


Table 4. Factor structure of the Prison Bullying Scale.

\begin{tabular}{|c|c|}
\hline $\begin{array}{l}\text { Factor 1: Admiring bullies and negatively appraising victims }(16.0 \% \text { of } \\
\text { variance) }\end{array}$ & Loading \\
\hline Prisoners who don't fit in deserve to be bullied & .70 \\
\hline I respect prisoners who can dominate others and get away with it & .67 \\
\hline Prisoners who can get away with bullying should be admired & .66 \\
\hline Victims don't deserve to have friends here & .66 \\
\hline I despise victims & .65 \\
\hline I wish I could dominate others and get away with it & .62 \\
\hline Prisoners only report bullying to get attention from other prisoners & .62 \\
\hline Victims usually enjoy getting bullied & .61 \\
\hline Victims can't be helped & .53 \\
\hline Its OK to spread rumours or to gossip about some prisoners & .53 \\
\hline Prisoners only report bullying to get attention from staff & .52 \\
\hline Victims ask to be bullied & .52 \\
\hline $\begin{array}{l}\text { It can be quite funny to see prisoners get upset when they are being } \\
\text { tormented by others }\end{array}$ & .52 \\
\hline Victims usually cause the bullying to happen & .50 \\
\hline Factor 2: Supporting and defending victims (12.4\% of variance) & Loading \\
\hline Its a good thing to help prisoners who can't defend themselves & .79 \\
\hline I like it when someone stands up for prisoners who are being bullied & .77 \\
\hline It makes me angry when a prisoner is picked on without reason & .72 \\
\hline Prisoners who are weaker than others should be helped & .70 \\
\hline Victims should be helped & .70 \\
\hline Bullying has a bad effect on the unit atmosphere & .59 \\
\hline Prisoners who bully others are childish & .57 \\
\hline
\end{tabular}




\begin{tabular}{|c|c|}
\hline You should not pick on someone who is weaker than you & .54 \\
\hline Bullies are callous and care little about others & .46 \\
\hline You shouldn't make fun of people who don't fight back & .44 \\
\hline $\begin{array}{l}\text { Factor 3: Justifying bullying and considering victims as deserving of } \\
\text { being bullied ( } 11.2 \% \text { of variance) }\end{array}$ & Loading \\
\hline $\begin{array}{l}\text { I can't stand prisoners who keep running to staff when someone picks on } \\
\text { them }\end{array}$ & .77 \\
\hline Being bullied does some prisoners good & .65 \\
\hline Bullying would not happen if victims stood up for themselves more & .62 \\
\hline It's OK to call some prisoners names & .61 \\
\hline Prisoners who are unable to look after themselves really annoy me & .61 \\
\hline $\begin{array}{l}\text { If a prisoner is going to let themselves be bullied, they deserve to be } \\
\text { ridiculed }\end{array}$ & .59 \\
\hline Its ok to hit some prisoners & .54 \\
\hline Prisoners who are weak are just asking for trouble & .44 \\
\hline I wouldn't be friends with prisoners who let themselves be pushed around & .42 \\
\hline Factor 4: Bullies as skilled (6.6\% of variance) & Loading \\
\hline Bullies are skilled at controlling others & .78 \\
\hline Bullies are physically stronger than other prisoners & .69 \\
\hline Bullies are mentally stronger than other prisoners & .48 \\
\hline It's better to be a bully than a victim & .46 \\
\hline Bullies help to keep 'order' on the unit & .43 \\
\hline
\end{tabular}


Table 5. Factor scores for PBS factors: Overall and for prisoners and officers

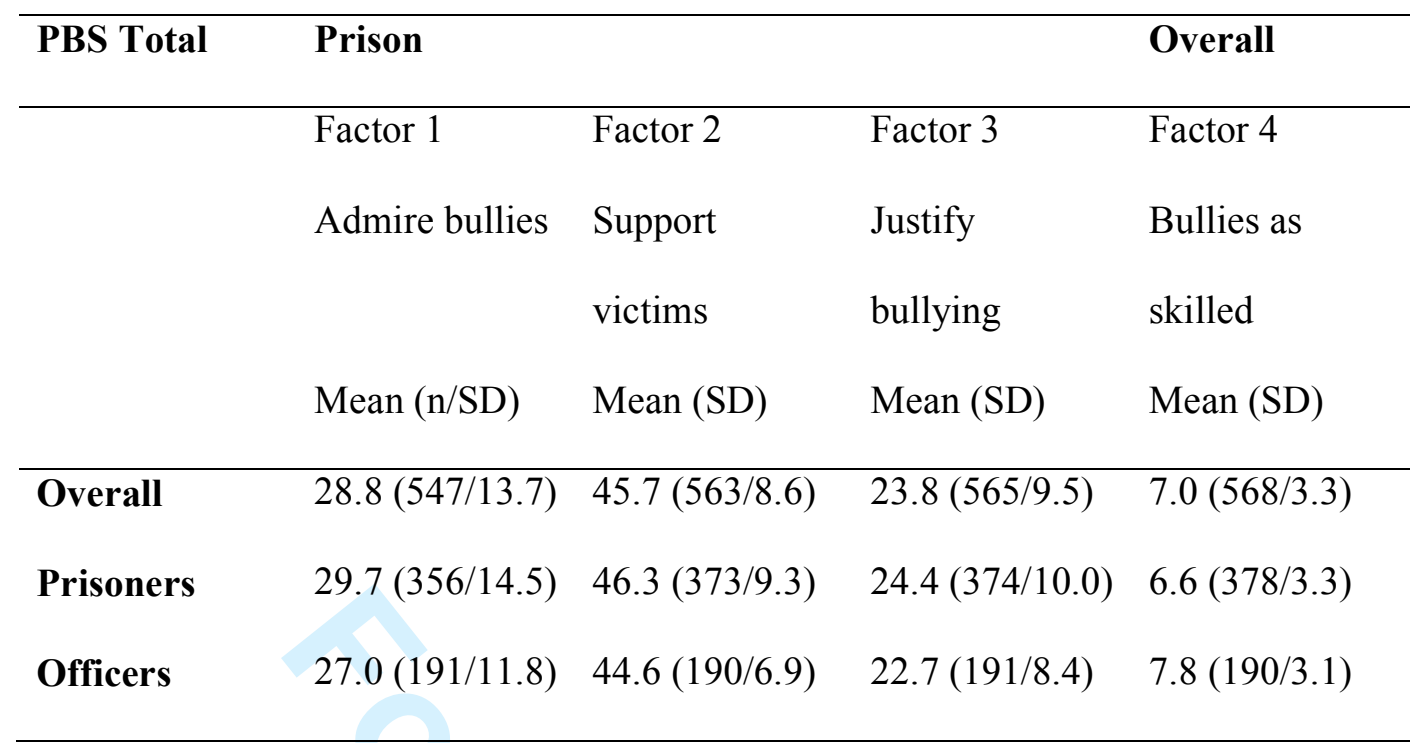


Table 6. Total PES scores overall and for prisoners and officers.

\begin{tabular}{lc}
\hline PES Total & Mean (SD) \\
\hline Overall $(\mathrm{n}=514,104$ missing) & $134.1(13.9)$ \\
Prisoners $(\mathrm{n}=330,93$ missing) & $132.9(15.4)$ \\
Officers $(\mathrm{n}=184,11$ missing) & $136.3(10.6)$ \\
\hline
\end{tabular}


Table 7. Factor structure of the Prison Environment Scale (PES)

\begin{tabular}{|l|l|}
\hline $\begin{array}{l}\text { Factor 1: Existence of a hierarchy and importance of material goods } \\
\text { (13.0\% of variance) }\end{array}$ & Loading \\
\hline A 'pecking order' exists between prisoners & .78 \\
\hline Prisoners at the top of the 'pecking order' have the most power and dominance & .72 \\
\hline $\begin{array}{l}\text { Levels exist between prisoners based on how much control and influence they } \\
\text { have }\end{array}$ & .69 \\
\hline It is important for prisoners to be seen as 'tough' by others & .66 \\
\hline Possessions are a valuable form of currency & .66 \\
\hline $\begin{array}{l}\text { Prisoners that are seen as weak and vulnerable are at the bottom of the 'pecking } \\
\text { order' }\end{array}$ & .60 \\
\hline Prisoners monitor what possessions other prisoners have & .58 \\
\hline The hierarchy seen in staff grades is seen between prisoners also & .56 \\
\hline Possessions are traded at high prices & .53 \\
\hline $\begin{array}{l}\text { It's easy for prisoners to break the rules when there are a lot of other prisoners } \\
\text { about }\end{array}$ & .50 \\
\hline Prisoners come into contact with many other prisoners everyday & .48 \\
\hline Factor 2: Lack of access to activities and space (8\% of variance) & Loading \\
\hline There are many meaningful activities to do* & .72 \\
\hline Prisoners feel bored because of the lack of activities to do & .63 \\
\hline Possessions are always provided when needed/requested* & .62 \\
\hline There are no activities to keep prisoners occupied & .62 \\
\hline There is not much physical space & .60 \\
\hline $\begin{array}{l}\text { Staff think about prisoners circumstances when applying prison rules and } \\
\text { regulations }\end{array}$ & .50 \\
\hline There is an emphasis on treating and releasing prisoners here & .47 \\
\hline Factor 3: High predictability of staff supervision (6.5\% of variance) & Loading \\
\hline Prisoners always know when staff will be present & .75 \\
\hline Prisoners always know where staff will be present & .70 \\
\hline Staff supervision is predictable & .60 \\
\hline Factor 4: Core beliefs: Accepting bullying (6.2\% of variance) & Loading \\
\hline Bullying can't be stopped so there is no point trying & .76 \\
\hline Bullying is just part of prison life, nothing can be done to stop it \\
\hline Victims deserve to be bullied & .71 \\
\hline
\end{tabular}




\begin{tabular}{|l|l|}
\hline Prisoners who bully receive respect & .48 \\
\hline Factor 5: Reduced control (4.9\% of variance) & Loading \\
\hline There is [a lack of] emphasis on security and control here & .62 \\
\hline Prisoners generally follow prison rules and regulations here* & .61 \\
\hline Prisoners have nothing to lose by behaving badly & .45 \\
\hline There are too many prisoners for staff to supervise well & .42 \\
\hline Factor 6: Prisoner and prisoner-to-staff relationships (4.8\% of variance) & Loading \\
\hline Prisoners would help someone who is being bullied* & .52 \\
\hline Prisoners talk to staff on a regular basis* & .51 \\
\hline $\begin{array}{l}\text { Prisoners would tell a member of staff if another had broken a prison rule or } \\
\text { regulation* }\end{array}$ & .49 \\
\hline There is [not] a high turnover of prisoners & .47 \\
\hline There are [not] lots of new prisoners coming onto and leaving this unit & .42 \\
\hline
\end{tabular}

*Items are reverse scored and thus the opposite of the statement relates to the factor. 
Table 8. Factor scores on the Prison Environment Scale (PES): Overall and between prisoners and officers.

\begin{tabular}{llll}
\hline PES Factor & Samples & & \\
& & & \\
& Mean $(\mathrm{n} / \mathrm{SD})$ & Mean $(\mathrm{n} / \mathrm{SD})$ & Mean (n/SD) \\
& & & \\
\hline Existence of a hierarchy and & $31.9(330 / 15.4)$ & $37.2(190 / 4.4)$ & $33.7(542 / 6.44)$ \\
importance of material goods & & & \\
\hline Lack of access to activities and & $18.0(367 / 4.0)$ & $13.5(193 / 3.3)$ & $4.36(560 / 16.5)$ \\
space & & & \\
\hline Predictable staff supervision & $11.1(369 / 2.9)$ & $10.9(191 / 2.5)$ & $11.0(560 / 2.8)$ \\
\hline Core beliefs: Accepting bullying & $7.1(371 / 2.9)$ & $7.1(192 / 2.8)$ & $7.1(560 / 2.9)$ \\
\hline Lack of control & & & \\
\hline Prisoner and prisoner to staff & $6.1(367 / 1.8)$ & $6.2(192 / 1.4)$ & $6.14(559 / 1.72)$ \\
relationships & & & \\
\hline
\end{tabular}

